\title{
Fonio (Digitaria exilis (Kippist) Stapf): A Socially Embedded Cereal for Food and Nutrition Security in Senegal
}

Baye Magatte Diop ${ }^{1,2}$, Mame Codou Gueye ${ }^{1 *}$, Codjo Emile Agbangba ${ }^{1,3}$, Ndiaga Cissé ${ }^{1}$, Monique Deu ${ }^{4,5}$, Omar Diack ${ }^{2,6}$, Amadou Fofana ${ }^{5}$, Ndjido Ardo Kane ${ }^{6,7}$, Khadidiatou Ndoye Ndir ${ }^{8}$, Ibrahima Ndoye ${ }^{2}$, Ablaye Ngom ${ }^{2}$, Christian Leclerc ${ }^{4,5}$, Marie Piquet $^{7,8,10}$, Yves Vigouroux ${ }^{9}$, Leila Zekraoui ${ }^{7,8,10}$, Claire Billot ${ }^{4,5}$, Adeline Barnaud ${ }^{7,8,10}$

${ }^{1}$ Centre d'Etude Régional pour l'Amélioration de I'Adaptation à la Sécheresse (CERAAS), Institut Sénégalais de Recherches Agricoles (ISRA), Thiès Escale, Thiès, Sénégal ${ }^{2}$ Laboratoire de Biotechnologies Végétales, Faculté des Sciences et Techniques, Université Cheikh Anta Diop de Dakar (UCAD), Dakar-Fann, Sénégal ${ }^{3}$ Laboratory of Biomathematics and Forest Estimations, Faculty of Agronomic Science (FSA), University of Abomey-Calavi, 03 BP 2819, Cotonou, Bénin ${ }^{4}$ CIRAD, UMR AGAP, F-34398 Montpellier, France ${ }^{5}$ AGAP, Univ Montpellier, CIRAD, INRA, Montpellier SupAgro, Montpellier, France ${ }^{6}$ Centre National de Recherche Agronomique (CNRA), Institut Sénégalais de Recherches Agricoles (ISRA), Bambey, Diourbel, Sénégal ${ }^{7}$ Laboratoire National de Recherches sur les Productions Végétales, Institut Sénégalais de Recherches Agricoles (ISRA), Centre de recherche de Bel Air, Dakar, Sénégal ${ }^{8}$ Laboratoire mixte international Adaptation des Plantes et microorganismes associés aux Stress Environnementaux (LMI LAPSE), Centre de recherche de Bel Air, Dakar, Sénégal ${ }^{9}$ Département de Production Végétale, Ecole Nationale Supérieure d'Agriculture (ENSA), Université de Thiès, BP A296, Route de Khombole, Thiès, Sénégal ${ }^{10}$ Unité mixte de Recherche Diversité et Adaptation des Espèces (UMR DIADE), Institut de Recherche pour le Développement (IRD), Université de Montpellier, Montpellier, France

*mcodougueye1@gmail.com

Abstract Agricultural diversification with neglected and underutilized species is a viable way to sustainably increase the productivity of agrosystems. Understanding the social, cultural, and ecological roles of these species is crucial for their promotion. White fonio (Digitaria exilis), a neglected cereal endemic to West African Sahelian countries, is recognized as a crop for the future due to its cultural, nutritional, and economic values. In this study, we described fonio farming systems in Senegal through an ethnobotanical approach. As expected in family farming systems, farmers largely practiced diversified subsistence agriculture on small plots and relied on local seed exchange networks. The importance of fonio varied among agroecological zones, ethnic groups, and gender. In the Groundnut Basin, where agriculture is more mechanized, latematuring landraces of fonio are cultivated as a cash crop rather than a staple crop. However, in southern Senegal, where food shortages are recurrent, fonio is more widespread and the cultivation of both early- and late-maturing landraces contributes to local food security. These differences also reflect the cultural status of fonio: different among ethnic groups and more important for women than for men. Finally, the regressive dynamics of fonio cultivation in most regions emphasizes the need to develop integrated conservation and promotion strategies that take into account the diversity of social and agronomical roles of the plant.

Received August 2, 2017

OPENӘACCESS

Accepted June 14, 2018

DOI 10.14237/ebl.9.2.2018.1072

Keywords Family farming system, Neglected and underutilized species, Cereals, Agricultural diversification, Ethnobotany

Copyright (c) 2018 by the author(s) licensee Society of Ethnobiology. This is an open-access article distributed under the terms of the Creative Commons Attribution-NonCommercial 4.0 International Public License (https://creativecommons.org/licenses/by-nc/4.0), which permits non-commercial use, distribution, and reproduction in any medium, provided the original author and source are credited.

Supplementary Files available at ojs.ethnobiology.org/index.php/ebl/article/view/1072

\section{Introduction}

Climate change may have negative impacts on agricultural production (Kumar and Sharma 2013; Lobell and Gourdji 2012; Ward et al. 2014). Because small-scale family farms cannot invest in costly adaptative strategies, climate change may increase their vulnerability. One way to buffer this is to promote agricultural diversification (Lin 2011). For 


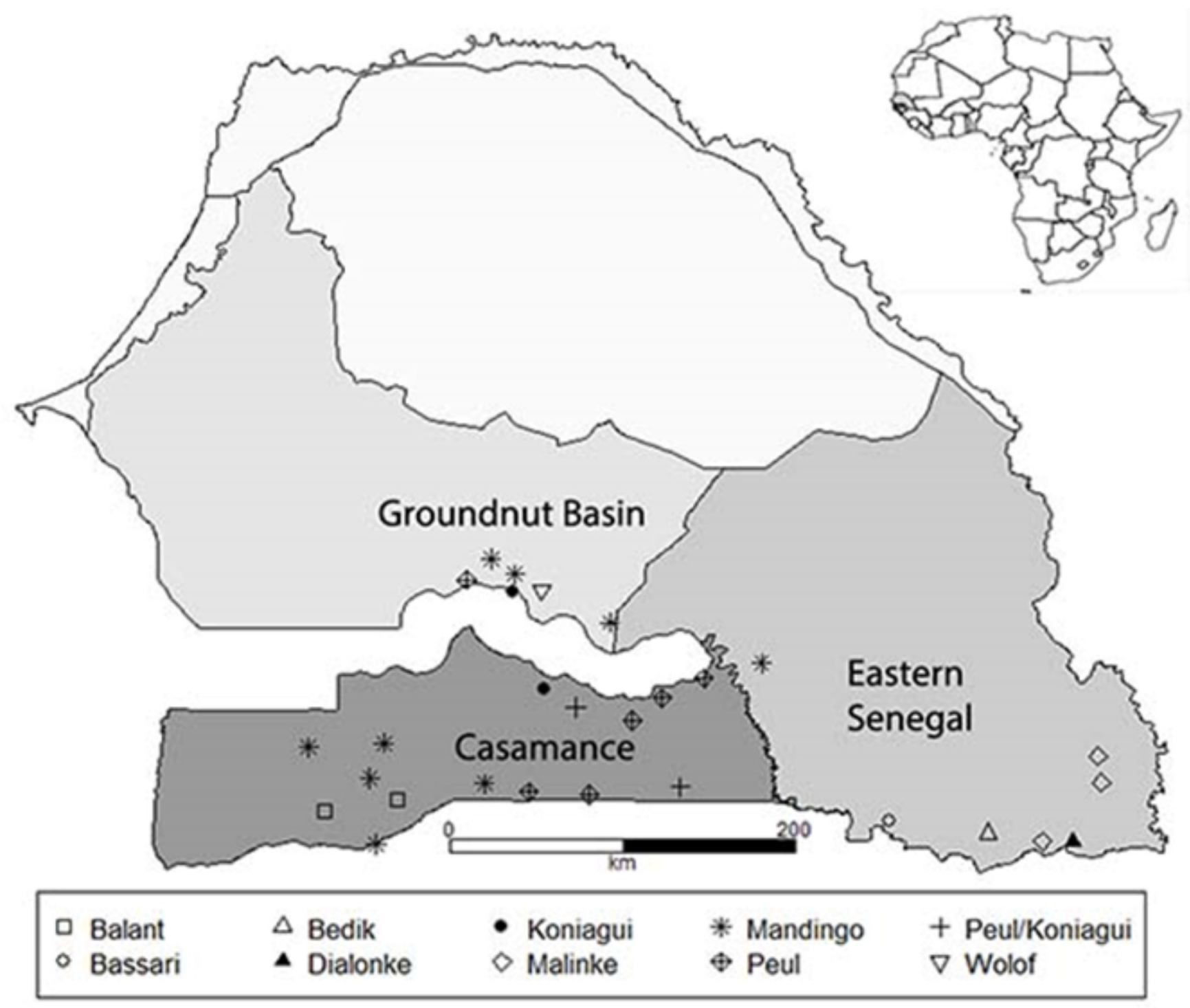

Figure 1 Map of Senegal showing the locations of the three study zones. Points symbolize the ethnic identity of the villages (based on the main ethnic group per village) surveyed in the Groundnut Basin (GB), in Eastern Senegal (ES) and in Casamance $(C)$.

this purpose, neglected and underutilized species (NUS) can play an important role (Hall and Rudebjer 2016). The growing interest in NUS also reflects an increasing trend in agriculture to develop new crops for local markets and exportation (Padulosi et al. 1999).

In this paper, we focus on white fonio (Digitaria exilis Stapf), a neglected crop endemic to West African Sahelian countries (Portères 1976), the cultivation of which extends from $8^{\circ}$ to $14^{\circ} \mathrm{N}$ latitude and from Senegal in the west to Lake Chad in the east (Cruz et al. 2011). For the Lambo and Akposso in Togo, the
Dogon in Mali, and the Peul, Bassari, Bedik, and Koniagui in Senegal and Guinea, fonio has great cultural value: it is the main food during traditional ceremonies such as marriages, baptisms, sacrifices, or funerals (Adoukonou-Sagbadja et al. 2006; de Lestrange and Passot-Guevara 1981; Dieterlen 1955; Gessain 1989). Fonio has a large diversity of local varieties (landraces) that differ in terms of life cycle duration; landraces with the shortest life cycle (less than two months) could thus play a useful role in preventing food shortages (Blench 2012; Gessain 1989; Gomila and Clarkson 1983; Portères 1955). 
In addition, fonio is considered to be one of the tastiest and most nutritious cereals in Africa (Jideani 1990). It contains a very low level of gluten, and while it does not have a high protein content, all twenty amino acids are present, in particular two essential ones (methionine and cysteine) which are lacking in most major cereals such as wheat, rice, sorghum, and barley (Vietmeyer et al. 1996). Fonio can thus contribute to nutrition security, an increasing concern for all countries (Asfaw 2006; Popkin et al. 2012). All these properties allow for the potential to generate significant financial returns for farmers, and, significantly, for women, who are traditionally involved in transformation and marketing (Paraïso et al. 2011; USAID 2008).

The southern region of Senegal has a long tradition of fonio cultivation (Portères 1955). The recurrence of food shortages in this region (Lo 1998; Ndao 2004) suggests that early maturing fonio landraces could have strategic importance (Portères 1955; Ruskin et al. 1996). However, cultivated on small areas (0.25 to 1 ha, after Cruz et al. 2011), it remains a marginal cultigen representing less than $1 \%$ of overall cereal production in Senegal (ANSD 2014a). Moreover, only $20 \%$ of the fonio marketed and consumed within the country is produced locally (USAID 2008).

For all these reasons, fonio has received particular attention in diversification policies (Fall and Lo 2009). Until now, research has mainly focused on technical itineraries and mechanization (Gueye et al. 2015; Kanfany et al. 2016), neglecting seed management and farmers' practices related to their perceptions of fonio diversity (Diedhiou 2008).

The objective of this study was to characterize the socio-cultural and ecological role of fonio and its cultivation in Senegal. We describe the agrosystems integrating fonio and the related agricultural practices. We then analyze the seed management system and uses of fonio to give a comprehensive view of the recent dynamics of fonio cultivation.

\section{Methods}

Study Areas

The study was conducted in the fonio-producing regions of Senegal (central and southern Senegal) which are a tropical climate zone, between latitudes $12^{\circ} 18^{\prime}$ and $13^{\circ} 55^{\prime}$ North. These regions are characterized by climatic and agronomic differences and, to a lesser extent, by the ethnic composition of their populations (Figure 1).

The first region is located in groundnut-producing basin (Gray 2002) in central Senegal. This region, known as Groundnut Basin (GB), is characterized by relatively flat topography and a Sahelo-Sudanian climate (mean annual rainfall $724 \mathrm{~mm}$ ). Major crops are groundnut (Arachis hypogaea), cultivated mainly as cash crop, pearl millet (Pennisetum glaucum), and sorghum (Sorgbum bicolor subsp. bicolor). These species are sometimes associated with cowpea (Vigna unguiculata), condiments (Hibiscus esculentus, Capsicum annum, C. frutescens), sorrel (Hibiscus sabdariffa) and livestock raising (Pélissier 1966). Agriculture is mainly performed under rainfed conditions (fewer than 2\% of agricultural households practice irrigation [ANSD 2014a]) and is oriented towards a market economy led by groundnut (Pélissier 1966). It is highly heterogeneous in terms of ethnic occupation, with Wolof populations cohabiting with Mandingo, Peul, Serer, and Koniagui groups in the west, and in the east with Mandingo and Peul (Gessain 1989; Pélissier 1966).

The last two regions are located in the southern part of Senegal. The south of the Oriental Senegal region (OS) is characterized by the highest and hilliest reliefs in the country. Climate is sub-Guinean with average annual rainfall of $1,103 \mathrm{~mm}$. Agriculture is mainly rainfed (fewer than $1 \%$ of agricultural households practice irrigation [ANSD 2014b]) and thus conducted from May to November. Agriculture is dominated by cereals: maize (Zea mays), sorghum, African rice (Oryza glaberrima), and fonio. However, local production of these cereals does not cover food needs (Ndiaye 2000). Livestock raising is a marginal activity and is conducted mainly by the Peul (Chataigner 1963; Ndiaye 2000). This area is dominated by the Malinke, associated with the Bedik, Bassari, and Dialonke.

The last region is the Casamance (C), partly isolated from the rest of Senegal by the narrow strip of Gambia. It is characterized by a flat relief. The climate is Sudano-Guinean, with mean annual rainfall of $1,048 \mathrm{~mm}$. The soils are relatively clayey and humus rich. Agriculture is mainly rainfed (ANSD 2014b), dominated by sorghum, maize, and African rice and combined with large livestock production (Pélissier 1966). Population density is low and ethnic composition of the population is heterogeneous. Mandingo and Balant populations predominate in the 
west, while the Peul and Koniagui are located in the east (Fanchette 1999b; Pélissier 1966).

\section{Village and Farm Surveys}

Villages were chosen with the help of officers of the agricultural extension services (Regional Rural Development Divisions DRDR) in order to cover the geographical distribution of the fonio growing area and to represent the diversity of ethnic groups growing fonio. Given that each crop can be considered a social object, attention was paid to select villages of medium size for farmers to belong to the same social exchange unit. Surveys were thus conducted in 28 villages: six villages in the Groundnut Basin, seven in Oriental Senegal and 15 in Casamance (Figure 1), with an average population of $475( \pm 229)$ inhabitants.

In each village, interviews with ten randomly selected individuals were performed, followed by a focus group discussion. Special attention was paid to achieving a $50 \%$ sex ratio per village. A total of 132 women and 138 men were interviewed with the help of DRDR agents for translation. At the village level, the questions focused on 1) village history, 2) the modernization of agriculture, evaluated through the use of mechanization, 3) the livestock, evaluated through cattle raising: low numbers of cattle $(<10)$, medium (10-50) and high (>50), 4) the distance from local markets, 5) the relations with extension services officers and non-governmental organizations (NGOs), 6) the state of fonio cultivation (increase, regression, or stability), 7) the association of species and landraces of fonio in the field, 8) and the three most consumed species.

At the level of individual farmers, information collected was related to 1) age and ethnicity, 2) names of all cultivated species and their uses (selfconsumption or sale), 3) names of abandoned species and the year in which each was abandoned, 4) areas devoted to fonio, 5) the relative importance of fonio (surface rank and citation rank in relation to other cereals) and its use (self-consumption or sale), 6) fonio sowing and harvesting periods, 7) growth cycle of each fonio variety, 8) seed selection (yes or no), and 9) seed origins: first source of acquisition and most recent source of acquisition (family, neighbors, markets, and others).

Statistical Analyses

Based on the ethnic group of each farmer, seventeen groups (Supplementary Table 1) were represented, of which eight encompassed more than five farmers. Subsequent analyses were performed on these eight ethnic groups ( $89 \%$ of the farmers).

Means and frequencies were calculated from data obtained from the surveys in order to describe agroecological zones, ethnic groups, and gender balance. Tests were carried out to evaluate the effects of region, ethnicity, and gender on the studied variables: Generalized Linear Model (GLM) with binomial error distribution was performed for binomial qualitative variables, while GLM with Poisson error distribution was performed for quantitative variables.

For all Generalized Linear Models, only the significant second order interactions were retained in the final model. The model was followed by the "backward" procedure coupled with a Chi square test, to determine the model values that maximize the probability of obtaining the observed data. When the factor was significant for the frequency data, the pairwise comparisons for proportions was implemented under the FMSB package (Nakazawa and Nakazawa 2015) and the pairwise.fisher.test function with Bonferroni correction was used to evaluate the difference between the pairs' modalities at the significance level of $5 \%$. For quantitative data, Tukey HSD paired comparison test of mean with Bonferroni correction was performed.

To evaluate the citation rank (based on the principle that the most frequently cited species that appear at the top of the list are considered culturally more important than those lower on the list [Borgatti 1999]) and area rank of fonio in relation to other cereals, an automatic classification of incomplete multivariate rank data (Jacques and Biernacki 2014) using the rankcluster function implemented in the Rankcluster package (Jacques et al. 2014) was performed. The probability that two farmers do the same ranking, $\pi$, is a scale parameter ranking between 0.5 and 1 . Ranking is considered homogeneous when $\pi$ tends towards 1 . All analyses were performed using software R 3.2.5 (R Core Team 2015).

\section{Results and Discussion}

Our results showed that in regions where fonio is cultivated, agriculture relied on family farming systems: primarily oriented towards subsistence, performed in small plots, and combining diverse crops with livestock. In these systems, fonio played different roles, from a crop buffering against food shortage, to a staple or cash crop, driven by different 
Table 1 Characteristics of the three agro-ecological zones and the farming systems.

\begin{tabular}{|c|c|c|c|}
\hline & $\mathrm{GB}^{\mathrm{a}}$ & $\mathrm{OS}^{\mathrm{b}}$ & $\mathrm{C}^{\mathrm{C}}$ \\
\hline Altitude (m) & 31 & 152 & 34 \\
\hline Rainfall (mm) & 724 & 1103 & 1048 \\
\hline Temperature $\left({ }^{\circ} \mathrm{C}\right)$ & 27 & 28 & 27 \\
\hline Climate type & Sahelo-Sudanian & Sub-Guinean & Sudano-Guinean \\
\hline Relationship with SDR and GNOs & $57 \%$ & $100 \%$ & $86 \%$ \\
\hline $\begin{array}{l}\text { Distance to local markets }(\mathrm{km}) \\
\text { [range] }\end{array}$ & $5.14[0-15]$ & $21.33[0-70]$ & $15.40[0-80]$ \\
\hline Mechanized agriculture & $50 \%$ & $14 \%$ & $13 \%$ \\
\hline Livestock score $^{d}$ [range] & $2.57[1-3]$ & $2[0-3]$ & $2.53[0-3]$ \\
\hline No. of species & 22 & 26 & 27 \\
\hline Mean no. of species per farmer (sd) & $5.16(2.24)$ & $4.97(2.59)$ & $5.22(2.10)$ \\
\hline Mean area of fonio per region (sd) & $0.69(0.65)$ & $0.36(0.27)$ & $0.88(1.04)$ \\
\hline$\%$ of farmers growing fonio & $49 \%$ & $76 \%$ & $73 \%$ \\
\hline
\end{tabular}

${ }^{a}$ Groundnut Basin ${ }^{b}$ Oriental Senegal ${ }^{c}$ Casamance ${ }^{d}$ 3=High livestock; 2=Medium livestock; $1=$ Low livestock; 0=No livestock.

management practices and by differences in the status accorded to the plant by different ethnic groups.

Integrated Family Farming Systems

As expected under family farming systems, farmers maintained high levels of agricultural diversity for consumption and used low levels of technology (Altieri 1999; Bellon 2004; Jarvis et al. 2008). Furthermore, agriculture was mainly associated with livestock, except in two villages (Table 1).

Thirty-three different species were recorded (Figure 2). The most cultivated species were sorghum, pearl millet, fonio, maize, and rice, together with groundnut (Figure 2). Each farmer cultivated on average five species $(\min =1, \max =12, \pm 2.2$; Table 1$)$ with significant variation among ethnicities (chisquared test, $\mathrm{df}=7, p$-value $=0.002$; Table 2). Bedik farmers cultivated fewer species $(3.12 \pm 2.55)$ than did Malinke $(6.81 \pm 2.56)$ or Mandingo $(5.77 \pm 2.58)$ farmers. Women $(5.5 \pm 2.36)$ cultivated significantly more species than men $(4.8 \pm 2.01$; chi-squared test, $\mathrm{df}=1, p$-value $=0.012$ ). The larger diversity among women may be explained by their involvement in home garden management, where a large diversity of crops can be observed (Howard 2003). However, no difference among agroecological zones was observed (chi-squared test, $\mathrm{df}=2, p$-value $=0.815$ ).

No matter the species, the home-consumption rate was high (between 50 to $100 \%$ ) except for dessert banana (Musa sp) and cotton (Gossypium hirsutum), which were entirely used as cash crops. There was no difference in species consumption between regions except for groundnut (Arachis hypogaea) and maize (Zea mays). Groundnut was entirely self-consumed in the Oriental Senegal, while only partly in Casamance $(74 \%)$ and in the Groundnut Basin (74\%). The difference was less striking for maize, which is entirely consumed in the southern Senegal (Oriental Senegal and Casamance) and less consumed in the Groundnut Basin (92\%) (Supplementary Table 2).

The level of modernization of agriculture (Table $1)$, measured by the level of mechanization per village, 

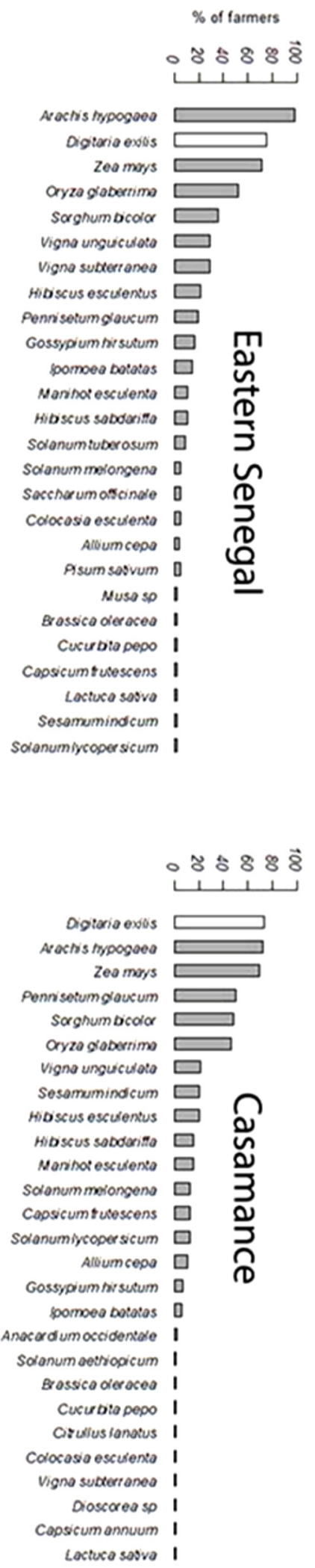

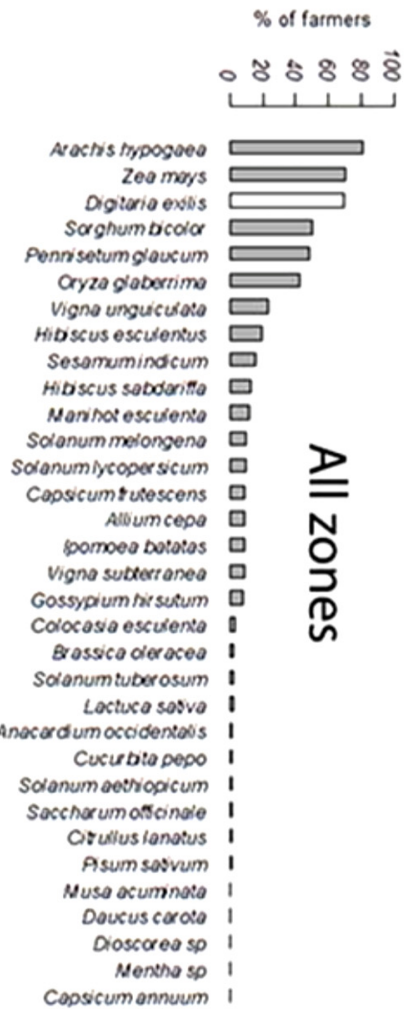

Figure 2 Species frequency. Figure shows the percentage of farmers who cultivated each species by region. White=fonio, gray=other species. 

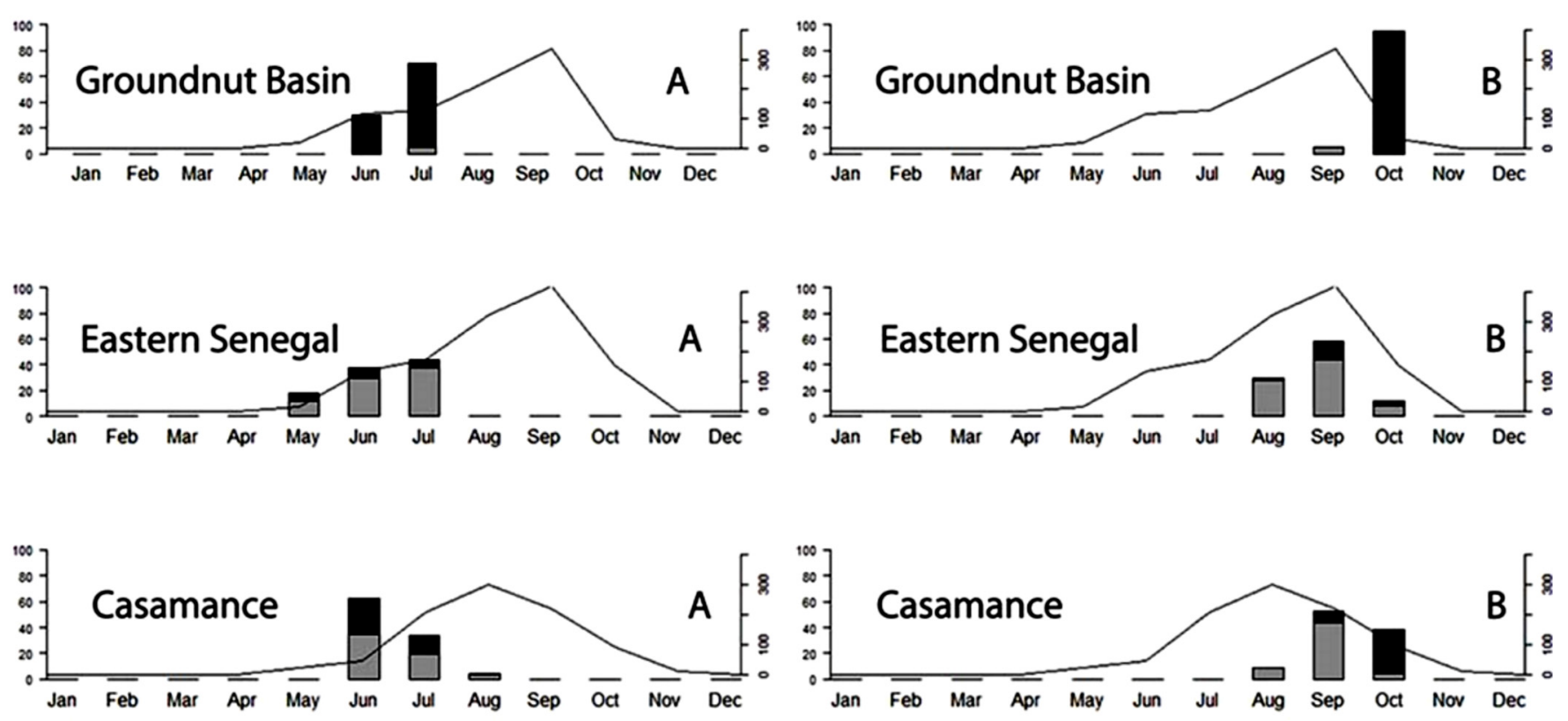

Figure 3 Fonio sowing $(A)$ and harvesting (B) periods in relation to rainfall (ANACIM 2015). Left $Y$ axis: \% of farmers, right $Y$ axis: Rainfall $(\mathrm{mm})$. Gray=\% of early-maturing landraces, black=\% of late-maturing landraces.

was low in Southern Senegal (14\% in Oriental Senegal and $13 \%$ in Casamance). In this region, away from major large cities, agriculture dynamics reflects the limited impact of government policy (Fanchette 1999b; Stirling 2012). In contrast, in the Groundnut Basin, half of the farmers benefited from the generalization of mechanization in this region (Couty 1991).

\section{Cultivation of Fonio}

Fonio was mainly cultivated in pure culture fields $(70 \%$ of the villages) as in Togo (AdoukonouSagbadja et al. 2006). It was sometimes (30\%) associated with sorrel (Hibiscus sabdariffa) or gombo (Hibiscus esculentus), as in Guinea, Mali, and Burkina Faso (Cruz et al. 2011). While 33 different landraces of fonio were collected in our study, each farmer cultivated only a few landraces $(1.15 \pm 0.39)$ without significant differences in terms of landrace number among region, ethnicity, or gender.

Fonio is only cultivated during the rainy season on small plots (mean 0.74 ha \pm 0.91 ), compared to sorghum (1.25 ha \pm 1.14$)$ and pearl millet (1.58 ha \pm 1.17), which are grown on larger plots (Figure 3). It occupied the fourth largest area after rice, sorghum, and millet, and before maize $(\pi=0.6)$. Sowing is performed at the beginning of the rainy season, from May to July (Figure 3). Early sowing allows fonio to successfully compete with weeds. In southern Senegal and Casamance, where the rainy season begins earlier, some farmers start sowing in early May, while in the Groundnut Basin, sowing is mainly performed in July. In all regions, the early maturing landraces are harvested between August and September while the late maturing ones are mainly harvested in October. After the harvest, grains are kept in barrels in granaries and are consumed during the year as long as they are available while keeping part for the next season's seed.

Staple Food, Crop Providing Insurance against Food Shortage, or Cash Crop?

Fonio was cultivated by $74 \%$ of the farmers surveyed, with significant variation among regions $(49 \%$ in Groundnut Basin, $76 \%$ in Oriental Senegal, and 73\% in Casamance; chi-squared test, $\mathrm{df}=2, \boldsymbol{p}$-value $=0.004$ ). Furthermore, the size of fonio fields were significantly different between both ethnic groups and region (chisquared test, $\mathrm{df}=7, p$-value $=3.86 \times 10^{-5}$, and chisquared test, $\mathrm{df}=7, p$-value $=0.004$, respectively). These differences emphasize the relative roles and cultural importance of fonio in local agrosystems.

In the Groundnut Basin, where agriculture is more mechanized and people are less vulnerable to food shortage, fonio is mainly considered a cash crop: no villages cited fonio in the three main consumed 


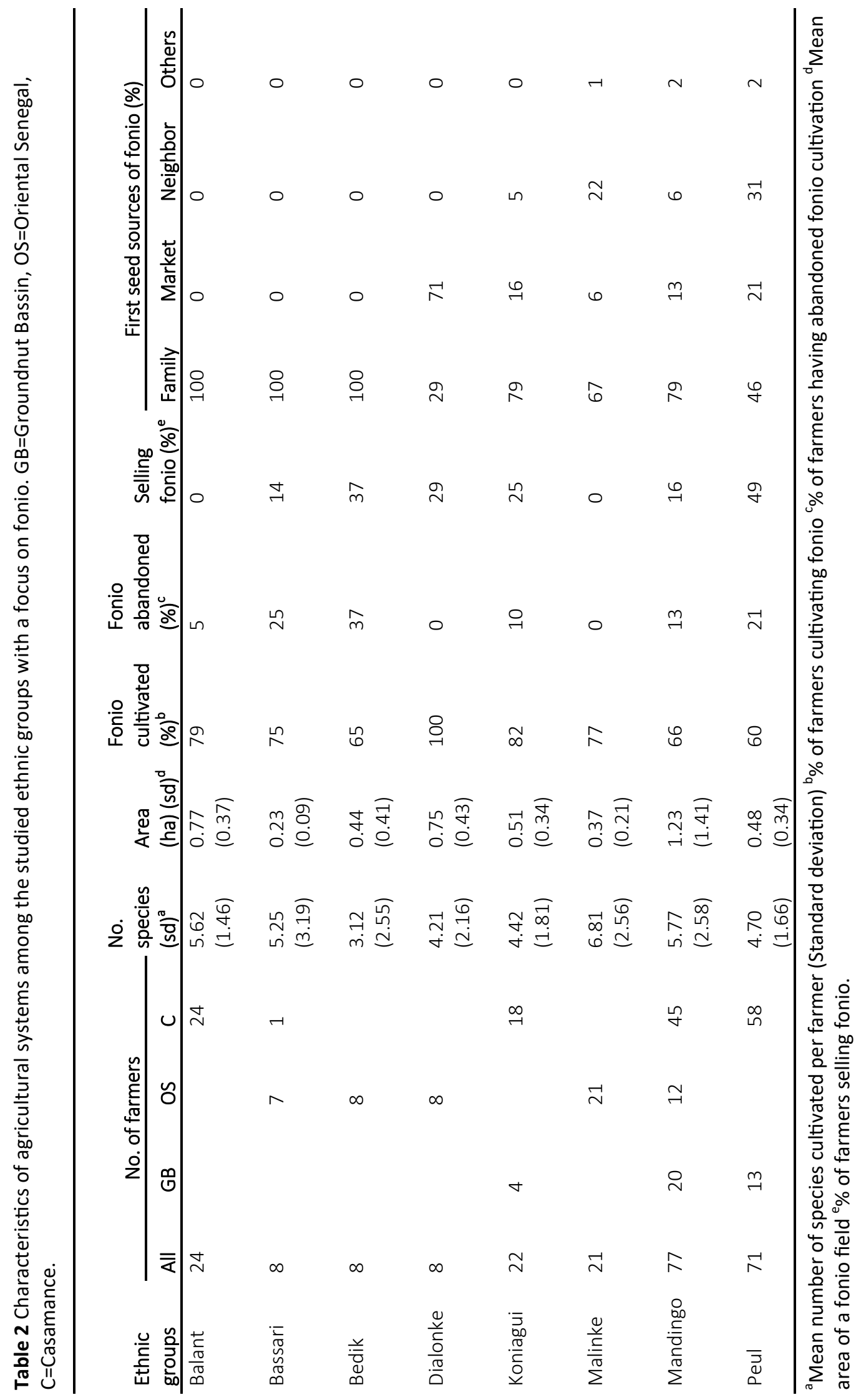


Table 3 Relative importance of fonio among cereals cultivated for each ethnic group.

\begin{tabular}{lllllll}
\hline \multirow{2}{*}{ Ethnic group } & \multicolumn{5}{c}{ Area Rank / Citation Rank } & \multicolumn{2}{c}{$\pi^{\mathrm{a}}$} \\
\cline { 2 - 5 } & Fonio & Maize & Pearl millet & Rice & Sorghum & $\pi^{2}$ \\
\hline Balant & $3 / 3$ & $4 / 4$ & $5 / 2$ & $2 / 5$ & $1 / 1$ & $0.63 / 0.65$ \\
Bassari & $4 / 2$ & $2 / 5$ & $5 / 4$ & $1 / 1$ & $3 / 3$ & $0.77 / 0.78$ \\
Bedik & $4 / 1$ & $3 / 2$ & - & $2 / 3$ & $1 / 4$ & $0.74 / 0.80$ \\
Dialonke & $1 / 2$ & $1 / 2$ & - & - & - & $0.60 / 0.60$ \\
Koniagui & $3 / 1$ & $4 / 4$ & $1 / 5$ & $5 / 3$ & $2 / 2$ & $0.71 / 0.70$ \\
Malinke & $4 / 4$ & $5 / 5$ & $2 / 2$ & $1 / 3$ & $3 / 1$ & $0.76 / 0.71$ \\
Mandingo & $2 / 2$ & $5 / 5$ & $3 / 4$ & $4 / 3$ & $1 / 1$ & $0.58 / 0.60$ \\
Peul & $4 / 4$ & $3 / 3$ & $1 / 1$ & $5 / 5$ & $2 / 2$ & $0.63 / 0.67$ \\
\hline
\end{tabular}

${ }^{a}$ Probability that two farmers do the same ranking

crops and over $58 \%$ of the farmers sold a part of their harvest. Ethnic groups that traditionally cultivate fonio (Koniagui, Mandingo, and Peul) are a minority under the influence of the Wolof who favor millet and sorghum (Pélissier 1966). Among the minority ethnic groups, Mandingo cultivate fonio on larger areas than do the Peul $(1.23 \pm 1.41$ ha vs $0.48 \pm 0.34$, $p$-value $=0.011)$. They cited it as the second most important species, while it is only the fourth most important for the Peul (Table 3). Since the order in which items are enumerated is not arbitrary but reflects their cognitive importance (Borgatti 1999; Henley 1969), this explains the higher level accorded to fonio by Mandingo.

In contrast, in southern Senegal (Oriental Senegal and Casamance), fonio cultivation was more widespread (Tables 2 and 3). Farmers in Casamance cultivated in larger areas than in Oriental Senegal $(0.88 \pm 1.04$ ha vs. $0.36 \pm 0.27 \mathrm{ha}, p$-value $=0.008)$. The lack of relief and the wide availability of soil in Casamance on the one hand, and the physical constraints of rugged terrain in Oriental Senegal, on the other hand, could explain the differences observed between $\mathrm{C}$ and OS regions. These differences also reflect a difference in cultural status of the fonio, more pronounced among the Mandingo where fonio is the "source of life", and even more significantly among Bassari, Bedik, and Koniagui, where it enters the divinatory rites (Dieterlen 1955; Gessain 1989). For 89\% villages in southern Senegal (Mandingo, Balant and Koniagui), fonio represents a staple food consumed all year long. In southern Senegal, food shortages are recurrent (Lo 1998; Ndao 2004), and the cultivation of both early- and latematuring landraces (Figure 3) is one action in a strategy of resilience. Fonio thus plays an important role in local food and nutrition security. Despite the presence of the major players in post-harvest transformation in southern Senegal like the EIGs (Economic Interest Groupings) involved in the transformation and marketing of fonio (Cissoko 2016), a restricted number of farmers reported selling a part of their harvest $(14 \%$ and $17 \%$ in Oriental Senegal and Casamance, respectively). The fonio dedicated to local and urban markets in this area may thus be coming from other areas of production, such as Guinea, which supplies more $70 \%$ of the fonio marketed in Senegal (USAID 2008). This constitutes a deficit for producers and exposes the financial, technical, and social insufficiencies of the major players in post-harvest transformation (Gaucher 2014). 


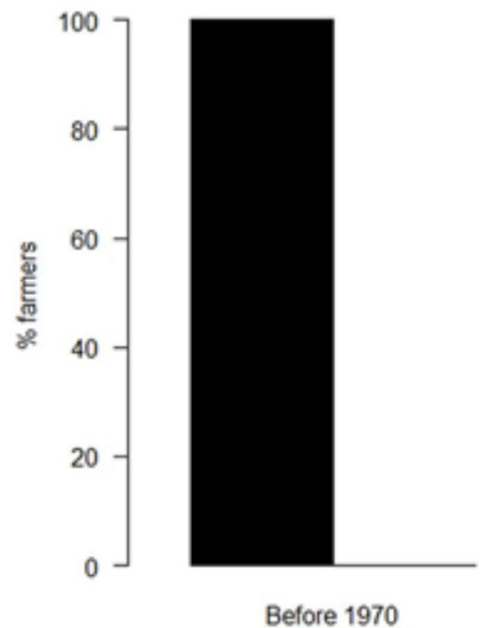

Before 1970

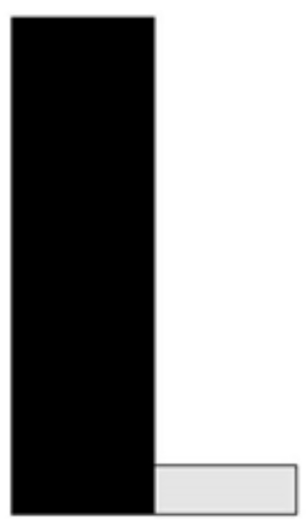

[1970-1990]

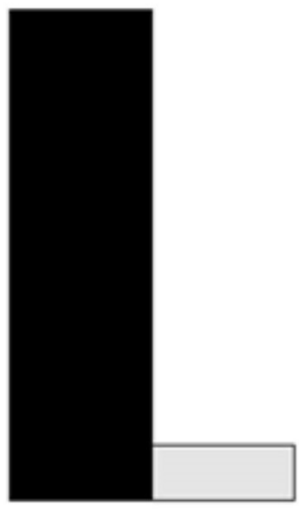

[1991-2000]

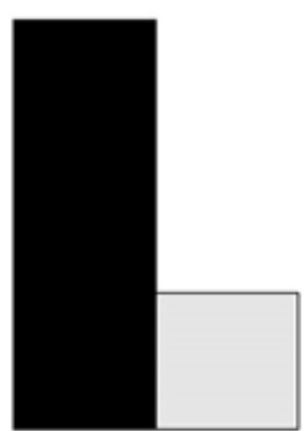

[2001-2013]

Figure 4 Change in the nature of the first acquisitions of fonio seeds. Black=acquisition from relatives, gray=acquisitions from market and NGOs.

\section{A Crop for Women's Empowerment}

Women appear to be key actors in fonio cultivation. With the exception of the Bedik, where men are at least equally involved (as already stressed by Gomila and Ferry 1966), women are more involved than men in the cultivation of fonio; it is significantly more cultivated by women $(79 \%)$ than men $(59 \%)$ (chisquared test, $p$-value $=0.002)$. While men cultivated fonio on larger areas $(0.77 \pm 0.83 \mathrm{ha})$ than women $(0.62 \pm 0.56 \mathrm{ha})$ (chi-squared test, $p$-value $=0.045)$, women dedicated larger areas among cereals to fonio (second rank of area, $\pi=0.66 v$ s third rank of area, $\pi=0.7)$ and cited fonio as the second most important species among cereals; for men, it was only the fourth most important ( $\pi=0.67$ vs $\pi=0.71$ ) (Table 4).

This preponderance of women is explained by the fact that the cultivation of fonio requires little physical effort but does demand meticulous and repeated operations during weeding and post-harvest operations, care often relegated to women (Howard 2003). In addition, women are the main actors of EIGs (Economic Interest Groupings) for the processing and sale of fonio (Cruz 2014), and fonio represents a source of financial income. Finally, women ensure, through the cultivation of fonio, good nutrition for their family (Kerr 2005).

However, since women and men are engaged in both different and complementary ways in the cultivation of fonio, their combined actions are necessary to the success of the food system as a whole. Mobilizing both men and women and promoting interaction between them is fundamental to increase production of fonio, which would thus increase economic interest in the crop and food security (Kerr 2005).

Circulation of Seeds

Reliance on the local seed exchange network was the

Table 4 Relative importance of fonio among cultivated cereals between genders.

\begin{tabular}{llllllll}
\hline & Gender & Fonio & Maize & Millet & Rice & Sorghum & $\pi^{\text {a }}$ \\
\hline Citation Rank & Women & 2 & 5 & 4 & 3 & 1 & 0.68 \\
& Men & 4 & 3 & 1 & 5 & 2 & 0.71 \\
\multirow{2}{*}{ Area Rank } & Women & 2 & 5 & 3 & 2 & 1 & 0.66 \\
& Men & 3 & 4 & 1 & 5 & 2 & 0.70 \\
\hline
\end{tabular}

${ }^{a}$ Probability that two farmers do the same ranking 


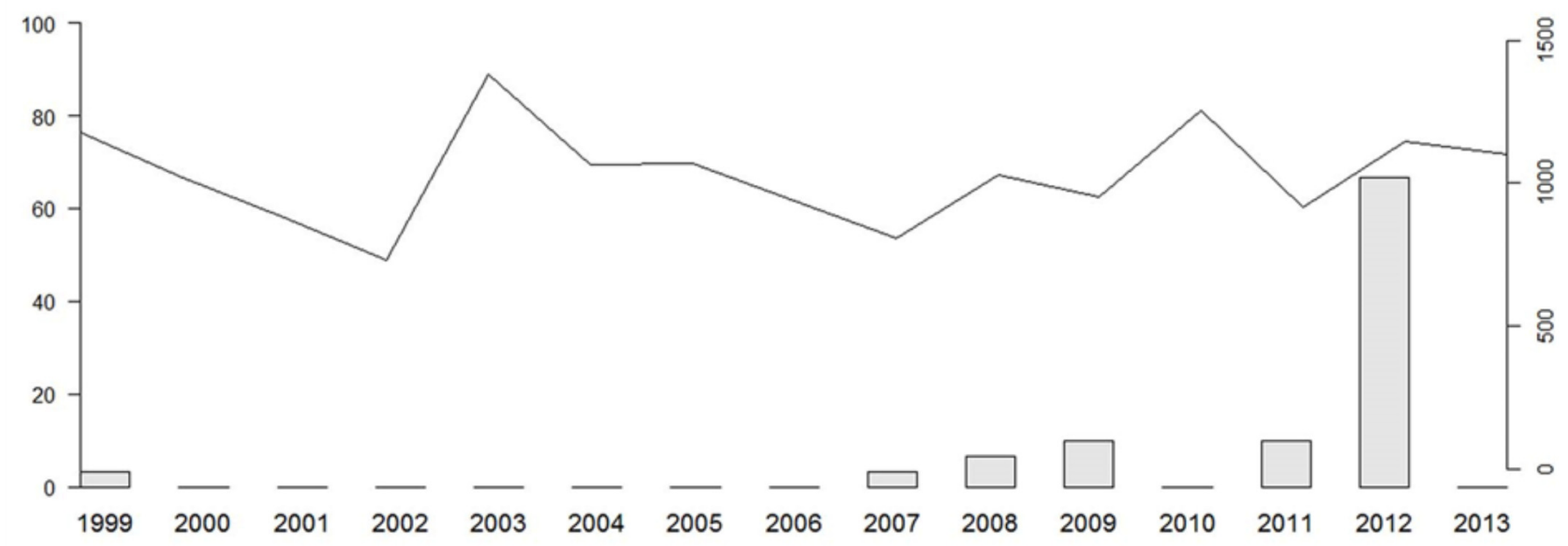

Figure 5 Frequency of abandonment of fonio cultivation (\% of farmers) and rainfall trend (mm) from 1999 to 2013 (ANACIM 2015).

most widespread means of acquiring fonio seed. The majority of farmers (85\%) acquired seeds for the first time through their relatives: parents (73\%) or neighbors $(12 \%)$. After this first acquisition, farmers mainly kept a part of their harvest to produce their own seeds for the next season. In 2013, 99\% of the sown seeds originated from previous harvests. These methods of seed acquisition ensure seed quality and a reduction in transaction costs (Almekinders et al. 1994; Bellon 2004).

However, the seed circulation pattern is changing, giving a larger importance to markets $(14 \%)$ and to a lesser extent to NGOs (1\%) as seed sources (Figure 4). Seed sources varied significantly among ethnic groups (chi-squared test, $p$-value $=0.002$ ), with Dialonke farmers $(71 \%)$ more concerned by this new form of seed acquisition than farmers belonging to the Balant, Bassari, or Bedik groups ( $0 \%$ ) (Table 2). These changes can be linked to an increased use of markets or to the dismantling of traditional social institutions, as in Ethiopia (Samberg 2013). Indeed, in the specific case of the Dialonke, this change could result both from the loss of rigor in their chieftaincy system (Albenque 1967) and their proximity to a market (on average $2 \mathrm{~km}$ ). It can also be linked to social rules, as for Mandingo farmers (13\%), who find it difficult to ask their neighbors for seed, at the risk of losing their dignity (Niane 1989). Markets thus appear to be important sources of seed acquisition and contribute to diffusion of seeds among ethnic groups (Wencelius and Garine 2014).
Non-governmental organizations and farmer organizations represented potential seed sources whose contributions are likely to increase in the near future. In the Groundnut Basin, USAID through the project Wulanafa in the eastern part, and the farmer organization Union of Mininky Valley Ecological Committees (UCEM) in the western part, have contributed to distribution and processing of fonio seeds in four of the six villages surveyed in this region. In Oriental Senegal villages, USAID through the projects Wulanafa and Yajeende have contributed to distribution and processing of fonio in four of the six villages surveyed. In Casamance villages, the activities of PADAER (Support Program for Agricultural Development and Rural Entrepreneurship), which have followed those of USAID since 2013, were noticed in two of the 15 villages surveyed. However, the low contribution of these NGOs $(1 \%)$ as seed sources despite their strong involvement in the villages could be linked to the lack of confidence in the seeds provided, confidence being a fundamental aspect to ensure reliable information about the seed (Badstue et al. 2006). That is why farmers prefer growing their own seeds or to acquire seeds from a supplier they know (Hodgkin et al. 2007; Lipper et al. 2009). This shows that seed distribution strategies must take into account social and cultural factors as well as the characteristics of innovation (Pannell et al. 2006). The seeds distributed by NGOs only concerned a restricted number of local landraces (three out of 33 landraces encountered in Senegal; Cissoko 2016), and did not include information on the characteristics of the landraces. This lack of reliable 


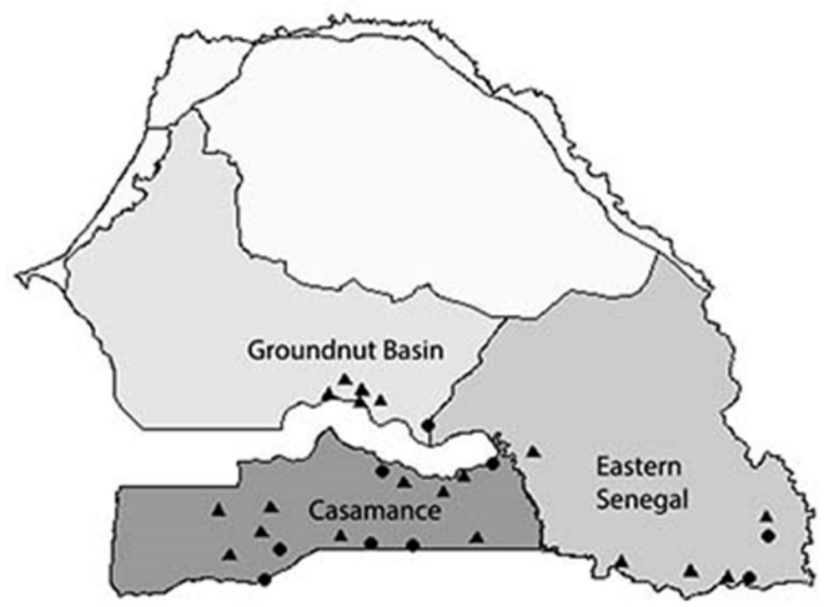

Figure 6 Changes in the frequency of fonio cultivation in the villages studied (increase: black triangle; decrease: black circle).

information did not favor their adoption. Thus, despite efforts by the state and by development agencies to supply farmers with seeds, these efforts remain insufficient (Cissoko 2016). The implementation of seed distribution is recent; the impacts of seed distribution on fonio diversity and conservation should thus be further documented.

\section{Dynamics of Fonio Cultivation}

In two-thirds of the villages $(68 \%)$, farmers noted a decline in the cultivation of fonio during recent years. Furthermore, while $86 \%$ of farmers reported having cultivated fonio at least once during their life, only $74 \%$ grew it in 2013, exhibiting a dropout rate of $12 \%$, of which $8.9 \%$ occurred in 2012, a year preceded by a decrease in rainfall (Figure 5). This decline, spatially heterogeneous (Figure 6), was mainly due to lack of seeds $(36 \%)$, tedious post-harvest processing $(36 \%)$, and disinterest of young people $(21 \%)$ in favor of more productive species such as pearl millet or sorghum, or even for alternative activities such as gold panning in the Oriental Senegal, and reduced rainfall $(7 \%)$. One-third $(32 \%)$ of the villages experienced an increase in fonio cultivation. Farmers referred to the importance of fonio during food shortage periods (71\%), the ease with which it can be grown, and the opportunity to sell fonio to EIGs $(29 \%)$. Indeed, in villages where EIGs are involved in the processing of fonio, the revaluation of the price of fonio (400 FCFA for paddy fonio and 1000 to 1200 FCFA for transformed) increased its production, as shown by Cissoko (2016) in Oriental
Senegal, where production attained $1000 \mathrm{~kg} / \mathrm{ha}$ in some villages.

\section{Conclusion}

Fonio is definitely a socially-embedded cultigen. Indeed, only certain ethnic groups traditionally cultivate it, and it is always present in specific ceremonies. It is also used in different ways, driving differences among ethnics in its cultivation: when fonio is used as a cash crop, famers focus more on late-maturing landraces, whereas when it is used to ensure food security, seeds are acquired within the social group and mainly early-maturing landraces are cultivated. In southern Senegal where ethnicities traditionally growing fonio predominate, fonio is an essential crop in their agrosystems.

Fonio represents a food of choice as part of a sustainable development policy. It is widely integrated in the regions' agrosystems and has characteristics that make it ideal for food and nutrition security and for the empowerment of women. The regressive dynamics of fonio cultivation in most regions suggests the need to develop integrated conservation and promotion strategies that must take into account the diverse social and agronomical roles of the plant.

\section{Acknowledgements}

We are thankful to the West Africa Agricultural Productivity Program (WAAPP/PPAAO 2A) for funding research activities (CERA58ID06 SE to M.C. Gueye and the $\mathrm{PhD}$ thesis of B.M. Diop). We also thank farmers and local authorities for their consent and collaboration. We acknowledge Angélique Berger (CIRAD) for data collection. We thank the team of the Agropolis Resource Centre for Crop Conservation, Adaptation and Diversity (a flagship project of Agropolis Foundation) and the Plantadiv project (ANR) for constructive discussions on methodological aspects.

\section{Declarations}

Permissions: Not applicable.

Sources of funding: We are thankful to the West Africa Agricultural Productivity Program (WAAPP/PPAAO 2A) for funding research activities (CERA58ID06 $\mathrm{SE})$.

Conflicts of interest: None declared.

\section{References Cited}

Adoukonou-Sagbadja, H., A. Dansi, R. Vodouhè, and K. Akpagana. 2006. Indigenous Knowledge and 
Traditional Conservation of Fonio Millet (Digitaria exilis, Digitaria iburua) in Togo. Biodiversity and Conservation 15:2379-2395.

Agence Nationale de la Statistique et de la Démographie. 2014a. Bulletin Mensuel des Statistiques Économiques de Février. Available at: www.ansd.sn. Accessed June 20, 2018.

Agence Nationale de la Statistique et de la Démographie. 2014b. Rapport Définitif: Recensement Général de la Population et de l'Habitat, de l'Agriculture et de l'Elevage. Available at: http://www.ansd.sn/ressources/rapports/ Rapport-definitif-RGPHAE2013. Accessed June 20, 2018.

Agence Nationale de l'Aviation Civile et de la Météorologie. 2015. Données Pluviométriques du Sénégal de 1999 à 2013. Available at: www.ansd.sn. Accessed June 20, 2018.

Albenque, A. 1967. Note sur les Dialonké au Sénégal (Département de Kédougou). Cahiers du Centre de Recherches Anthropologiques 2:149-69. DOI:10.3406/ bmsap.1967.1509.

Almekinders, C.J.M., N.P. Louwaars, and G.H. De Bruijn. 1994. Local Seed Systems and Their Importance for an Improved Seed Supply in Developing Countries. Euphytica 78:207-216.

Altieri, M.A. 1999. The Ecological Role of Biodiversity in Agroecosystems. Agriculture, Ecosystems, and Environment 74:19-31.

Asfaw, A. 2006. The Effects of Obesity on DoctorDiagnosed Chronic Diseases in Africa: Empirical Results from Senegal and South Africa. Journal of Public Health Policy 27:250-64. DOI:10.1057/ palgrave.jphp.3200089.

Badstue, L.B., M.R. Bellon, J. Berthaud, X. Juárez, I.M. Rosas, A.M. Solano, and A. Ramírez. 2006. Examining the Role of Collective Action in an Informal Seed System: A Case Study from the Central Valleys of Oaxaca, Mexico. Human Ecology 34:249-73. DOI:10.1007/s10745-006-9016-2.

Bellon, M.R. 2004. Conceptualizing Interventions to Support On-Farm Genetic Resource Conservation. World Development 32:159-72.

Blench, R.M. 2012. Vernacular Names for African Millets and Other Minor Cereals and Their Significance for Agricultural History. Archaeological and Anthropological Sciences, October. DOI:10.1007/ s12520-012-0104-5.
Borgatti, S.P. 1999. Elicitation Techniques for Cultural Domain Analysis. In The Ethnographer's Toolkit, edited by J. Schensul and M. LeCompte, pp. 1-26. Altamira Press, Walnut Creek, CA.

Chataigner, A. 1963. Les Populations du Cercle de Kédougou. Cabiers du Centre de Recherches Antbropologiques 5:87-111. DOI:10.3406/ bmsap.1963.2144.

Cissoko, M.K. 2016. Le Fonio Blanc (Digitaria exilis (Kippist) Stapf): Appuis à la Filière et Facteurs Incitateurs à sa Culture dans la Région de Kédougou. Unpublished Master's Thesis, Département de Biologie Végétale, Université Cheikh Anta Diop, Dakar, Sénégal.

Couty, P. 1991. L'Agriculture Africaine en Réserve. Réflexions sur l'Innovation et l'Intensification Agricoles en Afrique Tropicale. Cabiers d'Etudes Africaines 31:65-81.

Cruz, J.F. 2014. Aval Fonio, Amélioration de l'Après Récolte et Valorisation du Fonio en Afrique Rapport Annuel. Amélioration de la Qualité et de la Compétitivité de la Filière Fonio en Afrique de l'Ouest. Cirad Montpellier 38.

Cruz, J.F, F. Béavogui, and D. Dramé. 2011. Le Fonio, une Céréale Africaine. Quae Éditions, Versailles Cedex, France.

De Lestrange, M. Th. and B. Passot-Guevara. 1981. De la Grossesse au Sevrage, Chez les Bassari, les Peul et les Boïn de Salemata (Sénégal Oriental). Journal des Africanistes 51:23-41. DOI:10.3406/ jafr.1981.2017.

Diedhiou, C.T. 2008. Analyse des Systèmes de Culture à Base de Fonio. Unpublished Master's Thesis, Département de Production Végétale, Ecole Nationale Supérieure d'Agriculture, Thiès, Sénégal.

Dieterlen, G. 1955. Mythe et Organisation Sociale au Soudan Français. Journal de la Société des Africanistes 25:39-76.

Fall, A.A, and M. Lo. 2009. Etude de Référence sur les Céréales: Mil, Sorgho, Maïs, et Fonio au Sénégal. CORAF/WECARD, Sénégal.

Fanchette, S. 1999a. Densité de Population et Intensification Agro-Pastorale en Haute-Casamance. Espace, Populations, Sociétés 17:67-81. DOI:10.3406/ espos.1999.1870.

Fanchette, S. 1999b. Migrations, Intégration Spatiale et Formation d'une Société Peule dans le Fouladou (Haute Casamance, Sénégal). In Figures Peules, edited 
by R. Botte, J. Boutrais, and J. Schmitz, pp. 165192. Karthala, Paris.

Gaucher, S. 2014. Les Contraintes au Développement des Entreprises de Transformation du Fonio au Sénégal Oriental: Dans le Cadre du Projet d'Amélioration de l'Après-Récolte et Valorisation du Fonio en Afrique (Aval Fonio). Unpublished Master's Thesis, Irc Montpellier SupAgro Institut des Régions Chaudes, Montpellier, France.

Gessain, M. 1989. Youkounkoun Revisité. Journal des Africanistes 59:163-83. DOI:10.3406/jafr.1989.2281.

Gomila, J. and M. Clarkson. 1983. Eléments pour une Ethnographie du Mariage et de la Reproduction Chez les Bédik (Sénégal Oriental). Anthropologie et Sociétés 7:131-163.

Gomila, J. and M. Ferry. 1966. Notes sur l'Ethnographie des Bedik (Sénégal Oriental). Journal de la Société des Africanistes 36:209-50. DOI:10.3406/ jafr.1966.1409.

Gray, J.K. 2002. The Groundnut Market in Senegal: Examination of Price and Policy Changes. Doctoral Dissertation, Department of Agriculture and Applied Economics, Virginia Polytechnic Institute and State University, Blacksburg, VA. Available at: http://hdl.handle.net/10919/28143. Accessed June 20, 2018.

Gueye, M., G. Kanfany, A. Fofana, M. Gueye, K. Noba, and J. Grove. 2015. Effect of Planting Date on Growth and Grain Yield of Fonio Millet (Digitaria exilis Stapf) in the Southeast of Senegal. International Journal of Biological and Chemical Sciences 9:581. DOI:10.4314/ijbcs.v9i2.1.

Hall, R.A. and P. Rudebjer. 2016. 3rd International Conference on Neglected and Underutilized Species (NUS): For a Food-Secure Africa. Accra, Ghana, 25-27 September 2013. Proceedings. Available at: https://cgspace.cgiar.org/handle/10568/78325. Accessed June 20, 2018.

Henley, N.M. 1969. A Psychological Study of the Semantics of Animal Terms. Journal of Verbal Learning and Verbal Behavior 8:176-84. DOI:10.1016/ S0022-5371(69)80058-7.

Hodgkin, T., R. Rana, J. Tuxill, D. Balma, A. Subedi, I. Mar, D. Karamura, R. Valdivia, L. Collado, L. Latournerie, M. Sadiki, M. Sawadogo, A.H.D. Brown, and D.I. Jarvis. 2007. Seed Systems and Crop Genetic Diversity in Agroecosystems. In Managing Biodiversity in Agricultural Systems, edited by
D.I. Jarvis, C. Padoch, and H.D. Cooper, pp. 77 116. Columbia University Press, New York, NY.

Howard, P. 2003. The Major Importance of "Minor" Resources: Women and Plant Biodiversity. International Institute for Environment and Development, Gatekeeper Series No. 112. Russell Press, Nottingham, UK.

Jacques, J. and C. Biernacki. 2014. Model-Based Clustering for Multivariate Partial Ranking. Journal of Statistical Planning and Inference 149:201-217. DOI:10.1016/j.jspi.2014.02.011.

Jacques, J., Q. Grimonprez, and C. Biernacki. 2014. Rankcluster: An R Package for Clustering Multivariate Partial Rankings. The R Journal 6:101110.

Jarvis, D.I., A.H.D. Brown, P.H. Cuong, L. ColladoPanduro, L. Latournerie-Moreno, S. Gyawali, T. Tanto, M. Sawadogo, I. Mar, M. Sadiki, N.T. Hue, L. Arias-Reyes, D. Balma, J. Bajracharya, F. Castillo, D. Rijal, L. Belqadi, R. Rana, S. Saidi, J. Ouedraogo, R. Zangre, K. Rhrib, J.L. Chavez, D. Schoen, B. Sthapit, P. de Santis, C. Fadda, and T. Hodgkin. 2008. A Global Perspective of the Richness and Evenness of Traditional Crop-Variety Diversity Maintained by Farming Communities. Proceedings of the National Academy of Sciences, USA 105:5326-5331.

Jideani, I.A. 1990. Acha—Digitaria exilis—the Neglected Cereal. Agriculture International 42:132-134, 143.

Kanfany, G., M. Gueye, D. Sarr, K. Noba, M. Sall, and M. Ndiaye. 2016. Agronomic Constraints to the Development of Fonio Millet (Digitaria exilis Stapf) in Senegal. In 3rd International Conference on Neglected and Underutilized Species (NUS): For a Food-Secure Africa. Accra, Ghana, 25-27 September 2013, 1-7. Bioversity International, Rome, Italy and International Foundation for Science, Stockholm, Sweden.

Kerr, R.B. 2005. Food Security in Northern Malawi: Gender, Kinship Relations, and Entitlements in Historical Context. Journal of Southern African Studies 31:53-74. DOI:10.1080/03057070500035679.

Kumar, A., and P. Sharma. 2013. Impact of Climate Variation on Agricultural Productivity and Food Security in Rural India. Economics Discussion Papers, No 2013-43, Kiel Institute for the World Economy, Kiel, Germany.

Lin, B.B. 2011. Resilience in Agriculture through Crop Diversification: Adaptive Management for 
Environmental Change. BioScience 61:183-93. DOI:10.1525/bio.2011.61.3.4.

Lipper, L., C.L. Anderson, and T.J. Dalton. 2009. Seed Trade in Rural Markets: Implications for Crop Diversity and Agricultural Development. Earthscan, London, UK.

Lo, M. 1998. La Culture du Fonio en Casamance: Réalités et Perspectives. In Actes du Premier Atelier sur la Diversité Génétique du Fonio (Digitaria exilis Stapf) en Afrique de l'Ouest, edited by S.R. Vodouhe, A. Zannou, and E.A. Dako, pp. 23-26. Bioversity International, Rome, Italy.

Lobell, D.B., and S.M. Gourdji. 2012. The Influence of Climate Change on Global Crop Productivity. Plant Physiology 160:1686-97. DOI:10.1104/ pp.112.208298.

Nakazawa, M. and M.M. Nakazawa. 2015. Package "FMSB": Functions for Medical Statistics Book with some Demographic Data. Available at: http:// minato.sip21c.org/msb/. Accessed June 19, 2018.

Ndao, M. 2004. La Malnutrition Infantile en AOF. Le Cas du Sénégal, 1930-1960. Annales de la Faculté des Lettres et Science Humaines 34.

Ndiaye, T. 2000. Etude des Systèmes Agro-Pastoraux et des Revenus dans le Tenda (Bandafassi).

Université Cheikh Anta Diop, Institut de Recherche pour le Développement, Dakar, Sénégal.

Niane, D.T. 1989. Histoire des Mandingues de l'Ouest: Le Royaume du Gabou. Karthala, France.

Padulosi, S., P. Eyzaquirre, and T. Hodgkin. 1999. Challenges and Strategies in Promoting Conservation and Use of Neglected and Underutilized Crop Species. In Perspectives on New Crops and New Uses, edited by J. Janick, pp. 140-45. ASHS Press, Alexandria, VA.

Pannell, D.J., G.R. Marshall, N. Barr, A. Curtis, F. Vanclay, and R.R. Wilkinson. 2006. Understanding and Promoting Adoption of Conservation Practices by Rural Landholders. Australian Journal of Experimental Agriculture 46:1407-1424.

Paraïso, A., A.C.G. Sossou, R.N. Yegbemey, and G. Biaou. 2011. Analyse de La Rentabilité de la Production du Fonio (Digitaria exilis S.) dans la Commune de Boukombe au Benin. Journal de la Recherche Scientifique de l'Université de Lomé (Togo) Série A 13:27-37.

Pélissier, P. 1966. Les Paysans du Sénégal. Les Civilisations Agraires du Cayor à la Casamance. Fabrègue, SaintYrieix, France.
Popkin, B.M., L.S. Adair, and S.W. Ng. 2012. Global Nutrition Transition and the Pandemic of Obesity in Developing Countries. Nutrition Reviews 70:3-21. DOI:10.1111/j.1753-4887.2011.00456.x.

Portères, R. 1955. Les Céréales Mineures du Genre Digitaria en Afrique et en Europe. Journal d'Agriculture Tropicale et de Botanique Appliquée 2:349_ 86. DOI:10.3406/jatba.1955.2235.

Portères, R. 1976. African Cereals: Eleusine, Fonio, Black Fonio, Teff, Brachiaria, Paspalum, Pennisetum and African Rice. In Origins of African Plant Domestication, edited by J.R. Harlan, J.M.J. De Wet, and A.B.L. Stemler. Mouton Publishers, The Hague, Netherlands.

R Core Team. 2015. R: A Language and Environment for Statistical Computing. R Foundation for Statistical Computing, Vienna, Austria.

Ruskin, F.R., M. Daffron, E. Mouzon, B. Simpson, and D. Osborn. 1996. Lost Crops of Africa Vol. 1: Grains. National Academies Press, Washington, D.C.

Samberg, L.H., C. Shennan, and E. Zavaleta. 2013. Farmer Seed Exchange and Crop Diversity in a Changing Agricultural Landscape in the Southern Highlands of Ethiopia. Human Ecology 41:477-485. DOI:10.1007/s10745-013-9579-7.

Stirling, P.F. 2012. Deconstructing "Community" in Community-Based Natural Resource Management (CBNRM): Investigating Traditional Method of Subsistence (TMoS), Traditional Ecological Knowledge (TEK), and Ethnic Diversity for More Effective Resource Management in the Kedougou Region of Senegal. Unpublished Doctoral Dissertation, Department of Geography, University of Waterloo, Ontario, Canada.

USAID. 2008. La Chaine de Valeur de la Filière Fonio au Sénégal: Analyse et Cadre Stratégique d'Initiatives pour la Croissance de la Filière. International Resources Group, Washington, D.C.

Vietmeyer, N.D., N.E. Borlaugh, J. Axtell, G.W. Burton, J.R. Harlan, and K.O. Rachie. 1996. "Fonio (Acha)". Lost Crops of Africa Vol. 1: Grains. BOSTID Publications, National Academies Press, New York, NY.

Ward, P.S., R.J.G.M. Florax, and A. Flores-Lagunes. 2014. Climate Change and Agricultural Productivity in Sub-Saharan Africa: A Spatial Sample Selection Model. European Review of Agricultural Economics 41:199-226. DOI:10.1093/erae/jbt025. 


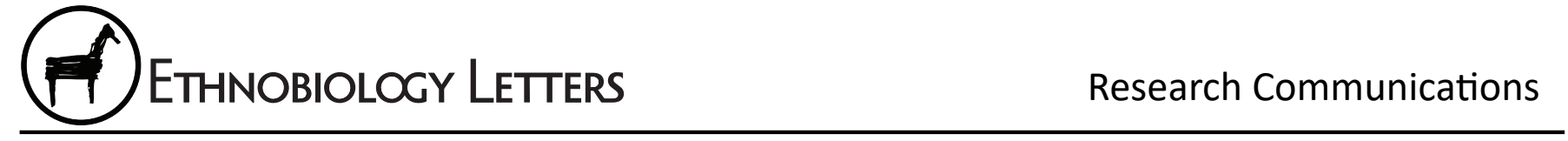

Wencelius, J. and E. Garine. 2014. Dans les Sillons de

l'Alliance. Ethnographie de la Circulation des

Semences de Sorgho dans l'Extrême-Nord du

Cameroun. Les Cabiers d'Outre-Mer 67:93-116.

DOI:10.4000/com.7082. 